\title{
LONG-TERM "ETHNICIZED SILENCES”, FAMILY SECRETS AND NATION-BUILDING
}

\author{
ELENA SOLER
}

\author{
CHARLES UNIVERSITY, PRAGUE
}

\begin{abstract}
This article demonstrates the dynamic relationship between long-term ethnicized silences, family secrets and nation-building in Central and Eastern Europe. How have modern nation-states been imagined and formed on the basis of these long-term silences? In order to illustrate what we believe could be the contribution to anthropology (principally to nationalism studies) enabled by introducing this analytical category of silences, in this research we will focus on a close analysis of the life story and identity journey of a self-identified "Slovak woman with Hungarian-Roma roots" who settled in the Czech Republic in 2009. Through this ethnographic example, and in an attempt to go beyond particularities, some of the themes covered are: what meanings, uses and processes of silences can we find in Slovakia, and what is their relationship to the construction of minorities and to an ethno-cultural model of nation-building (an imagined community)? In which domains and under which power relationships have long-term silences and hidden family secrets prevailed in everyday life? To what extent have those silence frameworks been negotiated and used as intergenerational strategies of family unity and protection? And finally, within the context of migration and the complex processes of Europeanization and globalization, how have those long-term, in this case "shamed", ethnicized Roma silences been contested and broken, and what is the meaning of this development (at micro and macro levels)? In other words, for nation-states that have long been imagined on the principle of ethno-cultural homogeneity, I ask what can long-term ethnicized silences tell us about the process of nation-building (from the bottom up) and the quality of our EU democracies? Where do we come from, where are we now and, at least in terms of a warning (due to the rise of xenophobic forms of populism and radical nationalism), where are we going?
\end{abstract}

KEYWORDS: silences, family secrecy, Roma, Slovakia, ethnonationalism, Central and Eastern Europe, migration

\section{INTRODUCTION}

The fall of the Berlin Wall on $9^{\text {th }}$ November 1989 and the years that followed generated a spiral of events that changed the face of the world provoking, as anthropological literature shows (Bridger and Pine 1998; Hann 200I), transitional processes of many kinds. This new European and international scenario was marked by the transition from totalitarianism to democracy and to a market economy, the reunification of Germany, the emergence of new nation-states as a result of the disintegration of the Soviet Union, 
the dissolution of Czechoslovakia ${ }^{1}$ and the fragmentation of Yugoslavia after a period of military conflicts. Today, three decades after these momentous events, new posttransitional scenarios have generated notable uncertainties and raised new questions.

Among the current questions and dilemmas confronting the $\mathrm{EU}^{2}$, those of how to respond to a worrying increase of xenophobia and radical nationalism are particularly troublesome. Being a part of the EU, as it has turned out, does not make member states immune to the rise of a social phenomenon which implies the categorization, stigmatization and rejection of the imaginary, uncomfortable "Other" (Todorov 20I4). Immigrants, local domestic minorities or anyone who represents "matter out of place" (Douglas 1966), even in some cases in their own homeland (e.g. the Roma or "Gypsies"), or who just through their presence, or even their possible appearance in the near future (as in the case of people escaping from war, as in Syria), are seen either as suspicious and/or as a potential threat to national unity and integrity. This model of the national "imagined community" (Anderson 1983) understood in ethno-cultural and even religious terms (e.g. Poland or Slovakia), and therefore with little space for the recognition of differences and fluid and multiple identities seems to be the one that has prevailed in some of the countries of Central and Eastern Europe, or at least to indicate the direction in which we are heading.

Based on the premise that, as Georges Kalamaras stated, "silence is not opposed to language ... rather silence and language work in a reciprocal fashion in the construction of knowledge" $(1994,8)$, in this article, I intend to demonstrate how, even after 1989, long-term ethnicized silences (in this case Roma, but the same could also apply to other ethnicities) and family secrets, which in some cases have even been strategically passed from generation to generation because they have not found a secure context to be broken and revealed, have a lot to say in the process of nation-building.

In other words, the term "ethnicized silences" proposed in this article aims to offer new theoretical anthropological insights into the dynamic relationships between silence, ethnicity, power and agency. For nation-states that have been based on the principle of ethno-cultural homogeneity (such as Slovakia and the Czech Republic) this term can be used to identify ethnic power dynamics within a hierarchical social structure. Therefore, these kinds of silences can be considered an integral element in the complex and dynamic processes of nation-building.

I On I ${ }^{\text {st }}$ January 1993, the split of the federal state of Czechoslovakia came into force, leading to the creation of two new states: the Czech Republic and Slovakia. This event, given its peaceful nature and in accordance with the so-called Velvet Revolution of 1989, is known as the Velvet Divorce. In this regard, it is worth mentioning the work of Czech anthropologist, Ladislav Holy (1996).

2 In 2004, within the frame of the enlargement of the European Union (EU), the Czech Republic, Slovakia, Hungary and Poland (known as the Visegrád group $\left(\mathrm{V}_{4}\right)$ were, along with other countries, incorporated as EU members. 


\section{CASE STUDY \\ FAMILY SECRETS AND LONG-TERM ETHNICIZED SILENCES: AN IDENTITY JOURNEY}

As anthropological literature reminds us (Basso 1970; Le Breton 1997), the meanings and uses attributed to silence (whether individual or collective) are neither self-evident nor stable across or even within different cultural and historical locations and contexts. Silence, just like verbal language or other corporal gestures, is a mode of human communication. Silence can be consciously and unconsciously forced upon people, by dint of the dynamics of different social, political, economic and even religious contexts, or it can equally just be voluntary. It is not the same to study silences under a totalitarian regime (e.g. Stalinism or Nazism), wherein thousands of people are forced into silence, as it is to study silences after 1989 and in post-transitional democratic Central European states (that since 2004 are EU members), which will be the socio-cultural, political and economic historical context this study is based on.

Considering long-term silence as a useful analytical category essential to understand nation-building (how the nation has been built, among other elements and factors, on the basis of imposed silences and self-silencing ${ }^{3}$ ), this article focuses on a close analysis of the life story and identity journey of a self-identifying "Slovak woman with Hungarian Roma roots", who settled in the Czech Republic in 2009. In so doing, the article attempts to cover and try to answer the following main themes and questions:

- What are some examples of the many meanings, uses and processes of silences and silencing as well as indirect forms of muteness that we can find in Slovakia, and what is their relationship to national minority constructions (ethnic and linguistic), and to a particular ethno-cultural model of nation-building based on an imagined "pure" community?

- In which domains, and under which power relationships, have long-term silences and family hidden secrets prevailed in everyday life?

- Following on from the work of Maurice Halbwachs (1950), to what extent have these silence frameworks or domains of silences been understood and used as intergenerational strategies and resources for family unity protection, stability or even resistance in order to provide answers to traumatic experiences or difficult situations of prejudice, indifference and social exclusion?

- How has the unspeakable and/or unsaid shaped people's subjectivities and the representation of the self, and what role have emotions played in silence practices?

3 In this regard, Michel-Rolph Trouillot, in the book Silencing the Past (1995) differentiated between story and History. Trouillot noted how power is everywhere: thus, any attempt to achieve objective national History will be impossible, because it will always be incomplete and intentionally fragmented due to the use and abuse of silences and silencing. 
- And finally, within the context of European transnational migration, under which conditions have these family secrets and long-term ethnicized, and even gendered silences been broken, even at the cost of generating intergenerational conflict within the family. And what is the underlying significance of such a development (at micro and macro levels)?

In order to try to respond to these questions, and primarily based on the selection and anthropological analysis of particular fragments of our informant's story (what a psychologist would call episodic memory), I have structured this article into three parts. And, the information on which it is based was collected in the spring of 2018 in the city of Prague through in depth face-to-face autobiographical interviews and some informal conversations, all conducted in English.

In the first part, as our informant who is in her mid-thirties is the daughter of a mixed ethnic couple (a Roma Slovak woman and a non-Roma Slovak man), I will focus on memories which relate to her childhood with her family in a small village in the Eastern part of Slovakia, and her youth and high school years away from home. These were periods of denial of Roma family roots, maintained secrets and conflicting ethnicized identity silences. The second part focuses on how those long-term or deep silences began to be questioned and challenged when she decided to go to London and stayed in this, as she called it, multicultural city for two years. And the third part covers the period from 2009 to present, during which she chose to settle in Prague. It is within this context of migration that our informant decided to move away from family secrets and self-silencing, and to instead celebrate all types of ethnic mixing and differences by proudly and publicly identifying herself as a Slovak woman with Hungarian-Roma roots.

As we shall see, in this research we encounter a relational, dynamic and fluid post-national identity journey which challenges the narrow ethno-cultural meaning of "Slovakness" and that can only be understood within the context of the process of Europeanization and globalization because, as our interlocutor stated in one of our interviews, "she had to go and live abroad in order to get home."

\section{Family Secrets and Long-term "Shamed" Silences: Childhood and Youth in Slovakia} The first time we met for an interview was in a café in Prague. After I explained the project I was involved in to her and why I considered that her life story and her perspective on some of the issues could be really relevant to it, I asked her to please introduce herself. She responded with this short, but relevant biographical introduction:

My name is Lenka. ${ }^{4}$ I was born in a small village close to Rožnava which is in the Eastern part of Slovakia, let's say two hours from Košice. Košice is the biggest city in East Slovakia. I was born in 
a family in which my mother is Roma and my father belongs to the majority: so, he is Slovak. I grew up with the idea that I am not Roma, and that everything in my life was related to my education and basically to Slovak culture, because I was in denial.

Then, when I asked Lenka why and what she meant by being in denial, she explained that her mother, who grew up in Communist Czechoslovakia (1948-1989), had felt discriminated against all her life. Lenka's mother felt discriminated not just because she was Roma or Gypsy, but also because she came from a very poor immigrant family: her parents had emigrated from Hungary to a small village in Slovakia (called Paskahaza in Hungarian, and Pasková in Slovak). As a result of this, Lenka's mother was not proficient in Slovak: her native tongue was the Romani language and she also knew some Hungarian. Then, we started to talk about the Hungarian population in Slovakia, which according to the census of 201 I constituted the largest ethnic minority, followed by the Roma ${ }^{5}$, and the historical explanation for the existence of this minority. In response, Lenka told me that she did not know if her grandparents had really crossed the Slovak-Hungarian border or whether the border had crossed them as a consequence of border changes in this southern part of Slovakia (formerly part of Hungary), an example of the wider phenomenon of border change in Central Europe.

Then, Lenka continued by telling me that this is why, after her mother met her father at their workplace and a few years later married him and moved to his village, she tried to forget about what she considered to be Roma culture and the Romani language, as both of these were important ethnic social markers. As Lenka put it:

It was not appropriate, otherwise she would not be able to be accepted in our village. Because in my village $98 \%$ per cent of people are Slovaks and they hate, really hate Roma. Because the only Roma who are in Slovakia, or in our village, are those who are really, let's say, you know [pause] marginalized.

As the conversation advanced, Lenka started to recall how her parents met and the family struggle they faced from both sides during the first years of their initially secret affair. It was an undercover secret which could not remain so for long, as her mother became pregnant and her body shape began to change. The evidence spoke for itself.

5 In the official Slovak Census of 20II, out of a total population of 5,440,602 Hungarians are the largest ethnic minority, with $8.5 \%$ of the population $(458,467)$ declaring themselves national (ethnic) Hungarians and $2 \%$ Roma. These are the official numbers, but the actual number of Roma is suspected to be much higher. So the question is: why did so many not want to be listed as Roma? One explanation could be that there was no opportunity to choose more than one nationality. This made the visibility of the diverse and multiple dynamic ethnic identities of Slovakia difficult to record, since it forced the population to choose one nationality over another. Another explanation, as I have been told several times in Bratislava and in Prague, is because it is just safer not to declare one's identity as Roma. 
On the one hand, Lenka's mother's Roma side of the family did not accept the relationship due to local norms and the fact that endogamy among such closed Roma communities is quite common. In fact, she had been expected to marry a Roma man who had already been chosen for her by her father and brothers. However, instead of following the family and local social expectations, - as Lenka put it, "because they just fell in love and they are together to this day" - she rather consciously decided to crosscultural and social ethnic boundaries (Barth 1969) by not marrying the man assigned, who according to her mother "was wild and uneducated", and instead carried on her relationship with the so-called Gadjo (e) (non-Roma). Lenka designated him a "Slovak white man", who according to her mother's Roma family, not in her own opinion, dishonoured the whole family when her mother became pregnant as a single woman without even knowing if he would take care and responsibility of her and their child, and not simply abandon them.

As anthropology of childbirth demonstrates, different social and cultural contexts provide scripts for all stages of reproduction, and people use these as social markers of group identity. In this context, therefore, the potential shame and loss of honour not just for Lenka's mother, but for the whole family through an unexpected pregnancy, as we can also see in other cultural and social settings and contexts besides Roma (PittRivers 1972), is connected with the idea that single women are expected to marry early and remain virgins until their wedding night. This defence of sexual purity explains why, during the pregnancy, in order to avoid any kind of local gossip and moral judgement Lenka’s mother had to be discreetly hidden at home. ${ }^{6}$ In other words, as anthropologist Emily Martin (1987) would say, this "gendered" silent pregnant body, which was an object of powerful male discourses (in this case, from the male members of the Roma extended family), represented something amoral and polluted that should be hidden from the public eye.

In this context it is important to bear in mind that, as anthropologist Maurice Bloch (1975, 3-9) noted when studying oratory and speech making among the Merina of Madagascar, most human knowledge is not acquired verbally. In the hierarchical oppressive situation in which she found herself, the obedient and silent attitude demonstrated by Lenka's mother can only be understood within the context of the long-term ingrained gendered silences women learn, mostly by observation, but also by being told what can be said and what not to say from early childhood. Gendered

6 In the Pasiego Valley of Northern Spain, for example, in the first part of the $20^{\text {th }}$ century women who became pregnant outside the Catholic holy sacrament of marriage, aside from emigrating had no other choice but to hide their pregnancy at home and to deliver the considered illegitimate newborn child in a church or in a local Maternity House, and remain silent about what happened all their lives (Soler 20II, 94). 
silences even muteness (Ardener 1975$)^{7}$, in most cases are passed from generation to generation, because within this strict social control, women just learn to be quiet.

However, as we have seen in recent anthropological literature, especially that which makes reference to post-colonialism, such as the study of Christine Salomon and Christine Hemelin (2008) in New Caledonia, the contesting and breaking of these gendered silences can function as a form of women's empowerment and agency. This is what happened afterwards through her mother's decision to continue with her loving relationship with Lenka's father, even though this decision also had deep-running consequences.

If these were the reactions of the Roma side of her family to her mother's relationship, on her father's side, the Slovak side as Lenka called it, the disapproval and objection was even deeper. In fact, the news was received as a complete shock. Lenka's narration continued as follows: "Yes, my father's family was very much against it. During the first year they had a fight, because his family was totally outraged. How is it possible? Our only son (because the rest had died, one in the Second World War and the other from meningitis) and with a Gypsy?" Lenka then tried to explain to me that they had the biggest dreams for him because he was already in his early thirties and came from a rich family. So they wanted the best Slovak bride for him. As a result, she said:

They kicked him out and he had to sleep for one year in a car, while my mother's family tried to keep her at home. But then my sister was born and my grandma heard and wondered, "Who is this child? If it is white, maybe it will be accepted." So, then my mum came with the child and grandma just fell in love, and this was regardless of what the child looked like.

Then, after a pause, she continued: "So, my mum, with not much knowledge of the Slovak language, left her place and lost almost all contact with her brothers and sisters, but not with her mother. She needed to get out: she escaped."

Thereafter, once this relationship was finally accepted (as she proudly emphasized), they were able to marry and settle in the father's village. This new family, consisting of Lenka's parents, her older sister and Lenka herself, became an important social unit in which shared silences and secrecy (related to her mother's Roma origin) became a part of everyday life. In other words - as we can see in other ethnographies, like the work of Pihla Maria Siim entitled Family Stories Untold. Doing Family Through Practices of Silence (2016) - these long-term secrets and silences, which at this moment served as a form of protection, were part of what made the family. As our informant stated while trying to justify her mother's decision to opt for this Roma origin denial, she did so "because it was better not to say."

7 The Muted Group Theory (MGT), developed by anthropologist Edwin Ardener in the I970s, is a communication theory related to power and gender. It focuses on women as a muted and marginalized group (via the use of language and in social discourse). 
If we focus on the dynamic relationship between memory, silence and forgetting in Lenka's story ${ }^{8}$, the term "structural amnesia" (also known as "selective amnesia") used by structural-functionalist anthropologists can fruitfully be applied. In Lenkas's narrative for example, we can see parallels with Laura Bohannan's work (1952) looking at family genealogies among the Tiv of Nigeria or in that of Evans-Pritchard (1977) among the Nuer of Sudan. For in both these authors studies, only ancestors who were considered to be relevant and convenient to the present where evoked from the past (in Lenka's case, the Slovak father's side of the family), while others (here, the maternal Roma side) were just deliberately forgotten and silenced.

At this point, I asked myself how Lenka emotionally experienced this Roma maternal family denial, and to what extent it affected the construction of her own subjectivity, the construction of the self? Was it internalized and fully accepted? Or the opposite: did it just bring her some kind of long-term anxiety and identity conflict?

Even though in Central and Eastern Europe, due to its complex history, movements of people and border changes, empirical data shows that a significant number of Roma are married to non-Roma (mixed ethnic marriages), the fact is that some of the children born from these unions still face emotional and psychological stress related to an identity crisis. And this is the case, as Romanian Roma activist Valeriu Nicolae and other scholars (Kusá and Findor 1999; Vaclavík 2019) have stressed, because the concept of a plurality and fluidity of ethnic identities and the acceptance of such identities - even though they are a common enough social reality - seems to go against the very core of the ways in which some of these European nations are imagined in ethno-cultural terms.

In other words, this reflection is corroborated both by observations that I made myself while living and working in the Czech Republic, and also by something I was told in an interview with one of the historians who work at the Romani Museum in the Moravian city of Brno (June, 2019) while we were talking about this project on longterm silences. We both agreed that the existence of this mixed-ethnic community, rather than being openly presented to the society as an excellent opportunity for combating racism and xenophobia, instead is most of the time ignored, silenced or self-silenced.

Lenka's childhood and the way she was raised, not just by her parents, but also by her Slovak grandmother, a very religious Christian woman who used to read the bible early in the morning by the light of a candle, is an example of a continuous forced denial of her Roma roots until her life trajectory changed. Before this moment came, family secrets and everyday ethnicized silences played a strategic role in enabling her to be fully accepted and move on, if not successfully then at least safely within

8 Connerton (2008) differentiates at least seven different types of forgetting: repressive erasure, prescriptive forgetting, forgetting that is constitutive in the formation of new identity, structural amnesia, forgetting as annulment, forgetting as planned obsolescence and also forgetting as humiliated silence. 
the so-called majoritarian or mainstream Slovak society. At the same time, as I aim to demonstrate in this article, through her self-silencing, Lenka, albeit unwittingly, contributes to a particular ethno-cultural model of nation-building.

One clear example of the identity struggle that Lenka experienced because, as narrative psychologist Jerome Bruner (1993) put it, she was possessed by a family story she could not tell, relates to her high school years. At school, Lenka's silencing of her Roma roots was not entirely successful because of the colour of her skin (which is a bit darker than the average in Slovakia), or as Lenka described "it sometimes just spoke for itself". She narrated this part of her life story as follows:

During my high school years, I went to a Lutheran Gymnasium and I had to do a [research] paper, and I chose the Roma, because at that time, you know, it was self-identification, trying to find your identity. However, I did not want anyone to know that I was half Roma, but I think some other students knew or suspected.

In fact, Lenka clearly remembered some of the prejudices and mocking that she experienced in school: this was mainly perpetuated by one classmate who used to call her "Gypsy". She then went on to emphasize that the Slovak word for "Gypsy" is "Cigán", and that it is very pejorative because "the association unfortunately is of being wild, uneducated, dirty and stealers."

After a few seconds of reflective silence, she continued: "Even my mum! She was afraid to come, you know, like to parents' meetings, because she really looks like a typical Gypsy. She was always pushing my father to go because she did not want them to see that she was Roma." She then told me that she felt a bit ashamed narrating this passage of her life, because her mother only went to her school for her graduation: so she went to school just on one day, the last that Lenka spent there.

In another interview, Lenka recalled how she felt she always had to prove herself in school because, even though she always performed well, there was always an additional pressure. As her mother once told her: "You have to prove yourself twice over, because in this society unfortunately you have this border. It is not your fault, but from the very start you are not equal. When you are called on the first day in class and they see you, then there are always doubts, always."

Even when we talked about language use, not just in school but equally in other areas of daily life, it was obvious that for Lenka not all languages had the same significance. Despite the fact that in most of our complex and plural societies the co-existence and use of different languages is common, these languages, especially within the context

9 The study of Iulius Rostas (20I2) about desegregation and Roma schooling in Central Europe shows not just how today's education is twice as difficult for Roma than it is for non-Roma, but also how, even if a Roma(ni) person is well educated, finding a good job and achieving success still remains a challenge. 
of nation-states, are usually hierarchically ordered and understood in terms of social differences (such as ethnic, religious, etc.).

In Slovakia, for instance, the Romani and Hungarian languages ${ }^{10}$ are the languages spoken by the two biggest ethnic minorities (those perceived as "others", as stated in the introduction, in their own homeland). On the one hand, the Romani language, with its internal variations and dialects, represents a stigmatized and historically persecuted and silenced language which was exposed to the assimilationist policies of the former Soviet Bloc governments (Hübschmannová and Neustupný 1996, 85-I09). The Hungarian language, in its turn, functions rather as a site of memory, to use Pierre Nora's term (1984). Hungarian is seen by the majoritarian Slovak society as a symbolic carrier of a conflictual past: of the period of forced Magyarization (Hungarization) during the time of national awakening when the territory of what is today Slovakia was under the rule of the Hungarian Kingdom (i.e. the implementation of the Hungarian Nationalities Law of I868).

The negative connotations associated with these languages explain why Lenka's mother with a Hungarian-Roma social background decided not to pass knowledge of these languages on to the next generations. "What would have been the point?" as Lenka rhetorically asked me. These languages were meant to be left behind within this self- silenced past. At the same time, Lenka and her sister were encouraged by their parents to learn other foreign languages, like English and German. These were languages which in this context were perceived in a pragmatic way, as a passport for a better future. In this regard, language can be seen an important social marker of continuity and change.

\section{Contested Long-term Silences Within the Context of Transnational Migration: London}

On graduating from high school, Lenka went to London with some schoolmates in order to improve her English. However, she liked it so much there that, even though her initial plan was to return to Bratislava and start theology studies at Comenius University, she decided to postpone her studies and stay in London for two more years, living on part-time low paid jobs in the fast food sector. It is within the context of migration, in which she had different new encounters with social diversity, that we see those ethnicized silences, which were an essential part of her identity construction and the way she grew up in Slovakia, start to be questioned. This occurred even to the

Io Even though in Slovakia these two languages (alongside others such as Czech, Bulgarian, Croatian, German, Ruthenian, Ukrainian and Yiddish) should be protected and promoted under the European Charter for Regional or Minority Languages (ratified by the Slovak government in 2002), and there are well-known Roma writers (such as. H. Lacková and T. Fabiánová), the fact is that Romani is still perceived by many people (both Roma and non-Roma) as a language of shame and poverty. This renders its acceptance, preservation and a willingness to learn it, or just pass it on, very difficult. 
point that her Roma "otherness" started to lose its initial meaning and, as she told me, became part of "us" and "me."

Beneath I offer some of the narratives focused on her two year stay in England which can help us to understand the different negotiations that shaped her relational identity journey:

\begin{abstract}
The first time I was in England I just liked it there, and then I just fell in love with an Afghan guy. Then, that summer in September, I was supposed to go to theology studies in Slovakia, but now I know that maybe I was too childish, but I was brave too because I called home and I said: "Mama, I am not going home". And she was agitated, saying like, "What? You don't have money, where are you going to live, what?" And I said, "Don't worry, it's going to be ok, it's my responsibility". Then I stayed there for two years.
\end{abstract}

At that point in the interview, I asked her whether she was working, and she responded: "Yes, I was working firstly in a pizza shop where that guy who I fell in love with was like a manager." I then asked if that man was still her boyfriend, now? (Let me point out that in another interview she had already explained that now she was living with her boyfriend, who was a foreigner). In response, she clarified:

\begin{abstract}
No, no, my boyfriend at that time was from Afghanistan, he came from hell. He was from Kabul and he told how they fired a bomb at his house. He was running, so the worst ever. So me, like a good girl with no problems, I really saw how hard life was and what childhood trauma is, and my problems just became like, what? Then my mum, instead of worrying about him, she was totally agitated and said, "Hey, I was trying to take you away from Roma, and now you are bringing a man from almost the same culture."
\end{abstract}

As this conversation advanced, I asked her if, in this new context, she had told anyone that her mother was Roma or had she kept it a secret as she had done in Slovakia? Her answer was as follows: "Yes, with pride, because everybody saw that I was different. Even though I could say I was Slovak, they kept on telling me that I did not look Slovak." Then I said, "But you are Slovak, no question about it?" Her answer was: "Yes, but when they say Slovak, you know what they mean. There is a certain meaning, like white Slovak. This is what I wanted to say, because for Roma people it is really hard, even with me: how do I identify?”.

This passage is important because, as I have commented in a previous work (Soler 2016, 70-89), the idea of whiteness related to ethnic Slovak identity, based on one religion (Christian) ${ }^{11}$ and one language, is still very ingrained within Slovak society,

II In 20II, the Slovak official data on religious affiliation was: Catholic Church (62\%); Greek Catholic Church (3.8\%); Reformed Church (I,8\%); Orthodox Church (0,9\%), Evangelical Church $(5,9 \%)$ and the rest are other confessions or people with no specified religion. In this regard, it is important not to forget that the Jewish population which had inhabited the Slovak lands since the $\mathrm{II}^{\text {th }}$ century 
especially in the period since Slovakia gained recognition as an independent sovereign nation after the split of the multinational state of Czechoslovakia in I993. In this regard, it is important to point out that this persistent ethno-nationalist trend (which in Slovak politics the far right People's Party Our Slovakia (L'SNS) would represent) has to be understood within the context of Slovakias national development from pre-communist times to the present (Harris 2019). This is why Lenka clearly differentiated between what was written in her passport (Štátne občiantsvo), a civil and political identity in which there was no question that she was Slovak, and her national identity (národnost).

In the book Ethnicity and Nationalism, Thomas Eriksen (2002) stressed that ethnicity is a dynamic and shifting aspect of social relationships, and that it can be consciously constructed. This idea resonates in the way Lenka, after her early years of struggling with self-identification, started to play with her identity, because in a multicultural city like London, as she put it, "you could be from anywhere." Then she went on:

Although I was conscious that I was trying to suppress that I was Roma when I went to England,
I just somehow felt much better with people from everywhere. I had friends from India, Pakistan,
Iran, and I was attracted so much to their culture and music. Even people when they saw me, like
Turkish people, told me that I looked like them. I love their dance, their music, and they are very
temperamental [pause]. So, maybe it is really in my genes that there is some attraction, something that
is unconscious... when you are Roma you still somehow find a way. I just felt these people are mine.

In this narrative we can see that, for Lenka, temporary emigration with all its associated experiences did not mean displacement and detachment from home: it was in fact the other way around. This is why she emphasized that from now on she would not have to choose between being either Slovak or Roma anymore. The meaning of Slovakness could embrace both, and was inclusive also of her sense of herself as a selfidentified European woman. As Lenka stated: "This is the thing when you travel and live abroad. I had horribly low self-esteem as well, because of how I looked. I even wanted those blue contact lenses (her natural eye colour is black), but then I thought this is my advantage, mixing, difference, and all those thoughts gave me much more confidence and freedom." Then, after a long pause, she added: "It is incredible that I had to move to England, to go abroad, to get home." 12

Given the multiplicity of social identities we all face, and how dynamic and relational they are, Lenka's reflections can fruitfully be compared with what Michael Ignatieff (rector and president of the Central European University in Budapest) stated in an interview for a Catalan newspaper when he was asked about Catalan nationalism.

was estimated before the Holocaust at I35,000. Today, there are only 2,600 self-identifying Jews in Slovakia. Some others prefer to keep this origin private and remain silent.

I2 The idea of home, as a fluid and dynamic concept, within this context can be metaphorically associated not just with family and the locality Lenka comes from, but also with her country, Slovakia. Therefore, it is both personal and subjective, but also acts as a place for collective identification (Davies 20I4, I54-I55). 
Ignatieff said that not having to choose one's identity (ethnic or national) over another, should also be treated as a right in itself: "the right not to decide" (La Vanguardia, October 22, 2019).

\section{Broken Silences and Intergenerational Family Conflict: Finally Settling in Prague} After her two years in London, Lenka returned to Bratislava and decided that she wanted to move on with her life and try to pursue her theology studies. This in turn led to her arriving in Prague through the Erasmus programme. However, once she started to work in an estate agency, a job she got on account of her knowledge of different languages, she decided to give up theology and enrol in a psychology programme, "in order to pursue her dream." Nevertheless, these changes and her new confidence in herself did not come without a social cost.

Once Lenka started to speak out about her Roma origin with pride, thus leaving those "shameful" ethnicized silences behind and celebrating her mixed, fluid identity, her relationship with her mother (who still lives in the small village in the eastern part of Slovakia) started to be affected to the point of creating a kind of intergenerational conflict. As she put it in one of our meetings, "It is sad, and actually the most ridiculous thing, that now when I am talking about Roma issues my mum is very angry and says to me 'Why do you care about that?' So this is kind of a funny situation: that I am trying to fight for my Roma origin, and this leaves her more alone, let's say."

Her mother is well aware of the structural, deep socio-economic inequalities and prejudices based on long-term ingrained stereotypes that Roma still face in Slovakia (Scheffel and Mušinka 20I9, I7-2I), as they do in most parts of Europe (Stewart 20I2). However, on this basis she believes that there is nothing to celebrate, because there is still a risk in being heard. So, just in case, it is better to keep quiet or remain in silence. In Lenka's case, on the contrary, due to the acquisition of the symbolic capital of education and language that enables her to move much more freely across national borders (Bryceson and Vuorela 2002, 8) and become detached from local and parental constraints, the situation is very different. Her mixed and dynamic relational, and to some extent post-national identity, has found a broader European and even globalized, as Habermas (2015) would term it, cosmopolitan space.

At the end of this conversation, I asked Lenka about her father, who is now almost seventy years old (because he was not really mentioned in any of the interviews). For it was her father who, along with his parents (Lenka's grandparents) passed on to her and her sister their ethno-cultural sense of belonging and their Slovakness, in other words their national affiliation. So I asked what was her father's general opinion of the Roma. She replied that her father connected Gypsy with being uneducated, and then added: "I told him that I was going to finish psychology. So, finally, he understood that we are not just Gypsies or [pause] not what he understood as being a Gypsy." 


\section{CONCLUSION}

In order to conclude in the spirit of the comparative and holistic nature of anthropology, we can say that this life story, like any life story, is unique but that the story underlying is not. We know that life stories and autobiographies are reconstructions of lived lives, and therefore, even if they are valuable, they are limited in terms of being reliable sources of information. However, through this brief analysis of Lenka's life narratives and identity journey, we can say that what can be told and what should rather be left out, who is being silenced or is self-silencing, and how or based on what (ethnicity, religion etc.), if analyzed can reveal a lot about the community and the society or situation under study.

We can agree that some silences are necessary, especially those related to intimacy, meditation and reflection, as these are profoundly needed in today's society. Likewise, there are even some moments and events when silence is demanded during social interaction (as for example during the practice of some ritual prayers). However, and this is the aim of this study and where I see its potential originality, it has come to my attention that there are also other types of silences - disturbing long term daily silences in Central and Eastern Europe - that are significantly different from all silence's abovementioned meanings. Shared ethniziced silences that have persisted over generations, illustrate therefore an on-going process of tracing symbolic mental barriers of belonging and exclusion (feeling or being forced to feel out of place) among the population.

Multiple, everyday long-term silences and undercover family secrets, I believe, are not sufficiently taken into consideration in anthropological studies (especially in nationalism studies). However, if these were to be fully recognized, gathered and analyzed, such silences could bring new insights into how the different modern nation-states have been, and are being, built in this part of Central and Eastern Europe. How this process of "othering" (this "us" versus "them") has been performed, in an inclusive or an exclusive way? Do we have space for the recognition of differences, and mixed and multiple "ethnic" dynamic identities and loyalties (like those felt and expressed by Lenka) in an overall sense?

In this regard, one of the points I want to make as a result of this research (which is part of a broader independent project on the dynamics of long-term silences and nation-building in Central Europe, in the Visegrád group countries) is that shared silences, as a strategic tool of communication, can create a community of silences (that is familiar, local etc.) and bring people together. Therefore, they can be an essential element for the functioning of the community. In this ethnographic case, for example, these silences made the family (it was "safer not to say"), while also contributing consciously or unconsciously to a particular ethno-cultural model of nation building in which diversity and multiplicity of ethnicities were just hidden and self-silenced. Therefore, we could say that locally silencing strategies can give a false image of a society much more homogenized than is actually the case. 
However, if contested and broken, as we have seen through this post-national identity journey of Lenka, these silences can also create intergenerational family conflicts, and even, at a more macro level, can tear a bigger community or nation apart.

Therefore, we could say that for nation-states that have been imagined and based on the principle of ethno-cultural homogeneity (e.g. the Slovak or Czech, along with other Central and Eastern European nation-states), these kind of ethnicized silences could be considered an integral element to consider in the complex and dynamic process of nation-building.

In other words, through looking at the dynamic relationships between long-term ethnicized silences (with their different meanings, uses and temporalities, and whether broken or not), family secrets and nation-building, which has been the goal of this research, we can ask what can we learn not just about the quality of our current democracies, but also about our past? Where do we come from, where we are now and, at least in terms of a warning - due to the rise of xenophobic forms of populism and radical nationalists sentiments (Hann 20I9, $\mathrm{I}-2)^{13}$ in the EU and worldwide in which old (e.g. Roma, and Jewish) and new ethnicized silences and self-silencing are on the rise - where are we going?

\section{REFERENCES}

Anderson, Benedict. 1983. Imagined Communities. London: Verso.

Ardener, Shirley. 1975. Perceiving Women. New York: Wiley.

Basso, Keith. H. 1970. "To Give Up on Words: Silence in the Western Apache Culture." South Western Journal of Anthropology 26: (3): 213-230.

Barth, Fredrik. 1969. Ethnic Groups and Boundaries: The Social Organization of Culture Difference. London: Little Brown \& Company.

Beck, Ulrich and Edgar Grande. 2007. Cosmopolitan Europe. Cambridge: Polity Press.

Bloch, Maurice, ed. 1975. Political Language and Oratory in Traditional Society. London: Academic Press. Bohanan, Laura A. 1952. "A Genealogical Chárter." Africa XXII: 30I-315.

Bridger, Sue and Frances Pine, ed. 1998. Surviving Post-Socialism. Local strategies and regional responses in Eastern Europe and the Former Soviet Union. London: Routledge.

Bryceson Deborah, and Ulla Vuorela, ed. 2002. The Transnational Family. New European Frontiers and Global Networks. Oxford: Berg.

Bruner, Jerome. 1993. Acts of Meaning. Cambridge: Harvard University Press.

I3 Chris Hann mentions that even though xenophobic forms of populism are worrying, in Budapest today, for example, more Hungarians are tired of Orbán's political propaganda and are switching to other media and taking to the streets to express their discontent: a trend which makes Budapest again a city of hope $(2019,2)$. In the case of Slovakia, one recent hopeful measure taken by the Slovak coalition government in order to recognize the plurality of Slovak society is that the current census of 202I (contrary to the previous one) will give an opportunity for Slovaks to list their affiliation to multiple national identities. 
Connerton, Paul. 2008. "Seven Types of Forgetting." Memory Studies. SAGE Journals.

Davies, Margaret. 20I4. "Home and State: Reflections on Metaphor and Practice." Griffith Law Review $23(2): 153-175$.

Douglas, Mary. 1966. Purity and Danger: An Analysis of Concepts of Pollution and Taboo. Routledge and Kegan Paul.

Eriksen,Thomas Hylland. 2002. Ethnicity and Nationalism. London: Pluto Press.

Evans-Pritchard, Edward. 1977. Los Nuer. Barcelona: Anagrama.

Habermas. Jürgen. 2015. "Democracy in Europe. Why the development of the EU into a Transnational Democracy is Necessary and How it is Possible." European Law Journal 2I (4): 546-557.

Harris, Erika. 2019. "Nation before democracy? Placing the rise of the Slovak extreme right into context." East European Politics 35 (4): 538-557.

Halbwachs, Maurice. 1950. La Mémoire Collective. Paris: Presses Universitaire de France.

Hann, Chris. M. 2019. "Anthropology and Populism". Anthropology Today 35 (I): I-2.

Hann, Chris. M, ed. 200I. Postsocialism: Ideals, Ideologies and Practices in Eurasia. London: Routledge.

Holy, Ladislav. 1996. The Little Czech and the Great Czech Nation. Cambridge: Cambridge University Press.

Hübschmannová, Milena and Jiři. V. Neustupný. 1996. "The Slovak -and Czech Dialect of Romani and its Standardization." International Journal of the Sociology of Language 120: 85-109.

Ignatieff, Michael. 02/10/2019. "La Contra." La Vanguardia. Barcelona.

Judt, Tony. 2005. Postwar: A History of Europe since 1945. London: Penguin Press.

Kalamaras, Georges. 1994. Reclaiming the Tacit Dimension: Symbolic Form in the Rethoric of Silence. Albany, NY: State University of New York Press.

Kusa, Zuzana and Andrej Findor. 1999. "Frames of the Slovak National Identity Constructions." Sociológia-Slovak Sociological Review 3I (6): 603-618.

Le Breton, David. 1997. Du silence. Paris: Editions Métailié.

Martin, Emily. 1987. The Woman in the Body: A Cultural Analysis of Reproduction. Boston: Beacon Press. Pitt-Rivers, Julian A. 1972. The People of the Sierra. University of Chicago Press.

Rolph-Trouillot, Michel. 1995. Silencing the Past. Power and the Production of History. Boston: Beacon Press. Rostas, Iulius. 20I2. Ten Years After. A History of Roma School Desegregation in Central and Eastern Europe. Budapest: Central European University Press.

Salomon, Christine and Christine Hamelin. 2008. "Challenging Violence: Kanak Women Renegotiating Gender Relations in New Caledonia." The Asia Pacific Journal of Anthropology 9: 29-46.

Scheffel, David Z. and Alexander, Mušinka. 2019. "Third Class' Slovak Roma and Inclusion. Bricoleurs vs Social Engineers." Anthropology Today 35 (I): I7-2I.

Siim, Pihla Maria. 20I6. "Family Stories Untold. Doing Family Through Practices of Silence." Ethnologia Europaea 46 (2): 74-88.

Snyder, T. 20II. Bloodlands. Europe between Hitler and Stalin. London: Vintage

Soler, Elena. 20II. Lactancia y Parentesco. Una Mirada Antropológica. Barcelona: Anthropos.

Soler, Elena. 2016. “'The Velvet Divorce’: Un Viaje hacia la Construcción de la Identidad Nacional Checa desde el Siglo XIX hasta la Disolución de Checoslovaquia." In Transiciones Culturales. Perspectivas desde Europa Central y del Este, edited by Elena Soler y Luís Calvo. Madrid: Consejo Superior de Investigaciones Científicas- CSIC. P. 47-9I.

Stewart, Michael, ed. 2012. The Gypsy 'Menace'. Populism and the New Anti-Gypsy Politics. London: Hurst Publishers.

Todorov, Tzvetan. 20I4. El Miedo a los Bárbaros. Barcelona: Galaxia Gutenberg.

Václavík, David. 20I9. "Shaping the Slovak Identity and the Manifestation Thereof in the Social Iconosphere. The Case of the Slovak National Museum.” Historická Sociologie 2: 35-52. 


\section{AUTHOR'S CONTACT:}

Elena Soler

Charles University

E-mail: alenasoler@gmail.com

ORCID: 0000-0003-4627-0578 